\title{
Release of Prostaglandins during the Contraction of Rat Aorta Induced by Ouabain and $\mathrm{K}^{+}-$Free Solution
}

\author{
Takumi SATOH and Hideaki KARAKI* \\ Department of Veterinary Pharmacology, Faculty of Agriculture. \\ The University of Tokyo, Bunkyo-ku. Tokyo 113, Japan
}

Accepted June 29, 1988

\begin{abstract}
Contractile effects of ouabain and $\mathrm{K}^{+}$-free solution on rat aortic strips were investigated. In the aorta without endothelium, application of ouabain or $\mathrm{K}^{+}$-free solution produced, after a latency period, a slow contraction reaching the maximum after 80-100 min. Pretreatment of the muscle with either indomethacin $(20 \mu \mathrm{M})$ or verapamil $(1 \mu \mathrm{M})$ decreased the maximum level of these contractions, whereas verapamil, but not indomethacin, prolonged the latency period. Simultaneous application of these inhibitors showed additive inhibitory effects. In the presence of endothelium, the latency period slightly increased without changing the maximum contractile tension. Methylene blue $(5 \mu \mathrm{M})$ shortened the latency period only in the aorta with endothelium. These results suggest that the contractions of rat aorta induced by ouabain and $\mathrm{K}^{+}$-free solution are due not only to membrane depolarization and $\mathrm{Na}^{+}-\mathrm{Ca}^{2+}$ exchange but also to the release of prostaglandins. Endothelium-derived relaxing factor seems to inhibit a part of these contractions.
\end{abstract}

Ouabain and $\mathrm{K}^{+}$-free solution have been shown to inhibit $\mathrm{Na}^{+}, \mathrm{K}^{+}$-ATPase activity and decrease the concentration gradient of $\mathrm{Na}^{+}$ and $\mathrm{K}^{+}$across the smooth muscle cell membrane $(1-5)$, resulting in membrane depolarization. Ouabain and $\mathrm{K}^{+}$-free solution induce contractions in various types of smooth muscles such as intestine (3-7), vas deferens (8) and blood vessels (9-13). Karaki et al. $(9,10)$ reported that in rabbit arteries, the contractions induced by ouabain and $\mathrm{K}^{+}$-free solution are mainly due to release of catecholamines. On the other hand, Ozaki and Urakawa $(12,13)$ reported that in guinea pig aorta, $\mathrm{Ca}^{2+}$ entry through $\mathrm{Na}^{+}-\mathrm{Ca}^{2+}$ exchange is involved in these contractions. In the present experiments, we examined the effects of ouabain and $\mathrm{K}^{+}$-free solution on rat aorta, which contains a very small amount of catecholamines possibly because this tissue does not have dense adrenergic innervation (14). Results indicate that the contractions of rat aorta induced by ouabain and $\mathrm{K}^{+}$-free solution are inhibited by indomethacin and

\footnotetext{
* To whom correspondence should be addressed.
}

also by verapamil, suggesting that these contractions are not only due to membrane depolarization and $\mathrm{Na}^{+}-\mathrm{Ca}^{2+}$ exchange but also to release of prostaglandins.

\section{Materials and Methods}

Tissue preparation: Adult male rats, weighing about $250 \mathrm{~g}$, were stunned and bled. Thoracic aorta was dissected out and cleaned of excess fat and connective tissues. Helical strips (2-3 $\mathrm{mm}$ wide and $5-6 \mathrm{~mm}$ long) were cut from the aorta.

Solutions: The composition of physiological salt solution (PSS) was as follows: $136.9 \mathrm{mM} \mathrm{NaCl}, 5.4 \mathrm{mM} \mathrm{KCl}, 1.5 \mathrm{mM} \mathrm{CaCl}_{2}$, $1.0 \mathrm{mM} \mathrm{MgCl}_{2}, 23.8 \mathrm{mM} \mathrm{NaHCO}_{3}$ and 5.5 $\mathrm{mM}$ glucose. High $\mathrm{K}^{+}$solution was made by replacement of $60 \mathrm{mM} \mathrm{NaCl}$ with equimolar $\mathrm{KCl}$. $\mathrm{K}^{+}$-free solution was made by the omission of $\mathrm{KCl}$. These solutions were saturated with a mixture of $95 \% \mathrm{O}_{2}$ and $5 \%$ $\mathrm{CO}_{2}$ at $\mathrm{pH} 7.4$ and $37^{\circ} \mathrm{C}$.

Recording of muscle tension: Each strip was attached to a glass holder under a resting tension of $1 \mathrm{~g}$ and equilibrated for $60 \mathrm{~min}$ in a $20 \mathrm{ml}$ bath. The contractile 
response was recorded isometrically with a force displacement transducer connected to a Nihon Kohden polygraph. In rat aorta with functionally intact endothelium, $1 \mu \mathrm{M}$ carbachol almost completely relaxed the muscle stimulated with $100 \mathrm{nM}$ norepinephrine $(15,16)$. In some experiments, the endothelium was removed by gently rubbing the intimal surface with a finger moistened with PSS (15-17). Muscle contraction induced by high $\mathrm{K}^{+}$solution was used as reference response because this contraction is not affected by the presence of endothelium $(15,16)$. Indomethacin, verapamil and methylene blue were added $15 \mathrm{~min}$ before the addition of ouabain or $\mathrm{K}^{+}$-free solution. Three parameters were used to characterize the contraction: 1) maximum contractile tension (peak tension), 2) period of time from the addition of ouabain or $\mathrm{K}^{+}$-free solution to reach the peak tension (time to peak tension), and 3 ) period of time from the addition of ouabain or $\mathrm{K}^{+}$-free solution to reach $10 \%$ of the peak tension (latency period).

Drugs: The drugs used were ouabain (Merck), verapamil hydrochloride (Sigma),
I-norepinephrine bitartrate (Wako), carbamylcholine chloride (carbachol. Tokyo Kasei), indomethacin (Sigma) and methylene blue trihydrate (Wako).

\section{Results}

Figure 1 ( $A$ and $B$ ) and Table 1 show the contractile responses of the aorta without endothelium to $1 \mathrm{mM}$ ouabain and $\mathrm{K}^{+}$-free solution. On the addition of ouabain and $\mathrm{K}^{+}$-free solution, muscle tension gradually increased after a latency period. As shown in Table 1, the latency period of the ouabaininduced contraction was shorter than that due to $\mathrm{K}^{+}$-depletion, while the peak tension levels and the time to peak tension were almost identical. The contractile response began to decrease after a 90-100 min exposure to ouabain or $\mathrm{K}^{+}$-free solution. It was also noted that the shape of these contractions, especially the latency period, showed some variations (compare Figs. 1 and 2, and Tables 1 and 2). In the following experiments, therefore, comparison was made using paired muscles obtained from the same rat.

The effects of an inhibitor of voltagedependent $\mathrm{Ca}^{2+}$ channel, $1 \mu \mathrm{M}$ verapamil.

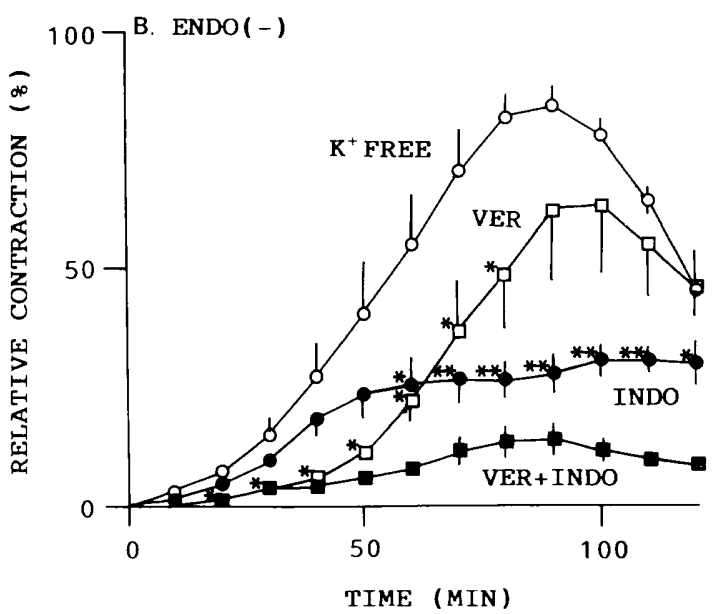

Fig. 1. Contractions induced by ouabain $(A)$ and $K^{+}$-free solution (B) in rat aortic strips without endothelium and the effects of $1 \mu \mathrm{M}$ verapamil (VER) and $20 \mu \mathrm{M}$ indomethacin (INDO). 100\% represents the magnitude of high $\mathrm{K}^{+}$-induced contraction. Verapamil and indomethacin were added 15 min before the application of ouabain or $\mathrm{K}^{+}$-free solution. Each curve represents the mean of 4 to 8 experiments and S.E. is shown by the vertical bar. * and **: Significantly different from the value in the absence of inhibitor at the level of $P<0.05$ and 0.01 , respectively. All of the points in the presence of both indomethacin and verapamil are significantly different from the value in the absence of these inhibitors at the level of $P<0.01$. ENDO(-): without endothelium. 
Table 1. Effects of indomethacin $(20 \mu \mathrm{M})$ and verapamil $(1 \mu \mathrm{M})$ on the contractions induced by ouabain $(1 \mathrm{mM})$ and $\mathrm{K}^{+}$-free solution in rat aorta without endothelium

\begin{tabular}{|c|c|c|c|c|}
\hline & $\begin{array}{l}\text { Time to } 10 \% \\
\text { peak tension } \\
\text { (min) }\end{array}$ & $\begin{array}{l}\text { Time to } \\
\text { peak tension } \\
(\mathrm{min})\end{array}$ & $\begin{array}{l}\text { Peak tension } \\
\text { !evel } \\
(\%)\end{array}$ & $N$ \\
\hline \multicolumn{5}{|l|}{ Ouabain } \\
\hline Control & $9.5 \pm 3.8$ & $101.3 \pm 7.7$ & $84.0 \pm 6.2$ & 8 \\
\hline Indomethacin & $7.9 \pm 3.6$ & $82.1 \pm 10.5$ & $43.9 \pm 10.5^{* *}$ & 4 \\
\hline Verapamil & $32.5 \pm 5.6^{* *}$ & $111.6 \pm 11.2$ & $48.5 \pm 11.1^{* *}$ & 4 \\
\hline \multicolumn{5}{|l|}{ Indomethacin } \\
\hline +Verapamil & $33.1 \pm 8.7^{* *}$ & $119.3 \pm 8.8$ & $16.1 \pm 5.4^{* *}$ & 4 \\
\hline \multicolumn{5}{|l|}{$\mathrm{K}^{+}$-free solution } \\
\hline Control & $21.1 \pm 4.5$ & $86.5 \pm 6.5$ & $83.8 \pm 4.1$ & 8 \\
\hline Indomethacin & $16.5 \pm 3.3$ & $104.5 \pm 20.5$ & $30.6 \pm 3.2^{* *}$ & 4 \\
\hline Verapamil & $42.2 \pm 5.1^{* *}$ & $97.3 \pm 12.0$ & $62.3 \pm 10.5^{*}$ & 4 \\
\hline \multicolumn{5}{|l|}{ Indomethacin } \\
\hline +Verapamil & $30.5 \pm 3.8$ & $91.0 \pm 15.6$ & $13.9 \pm 3.1^{* *}$ & 4 \\
\hline
\end{tabular}

Peak tension is shown by relative value taking the high $\mathrm{K}^{+}$-induced contraction as $100 \% . \mathrm{N}$ : Number of experiments. * ana **: Significantly different from the control at the level of $\mathrm{P}<0.05$ and 0.01 , respectively.
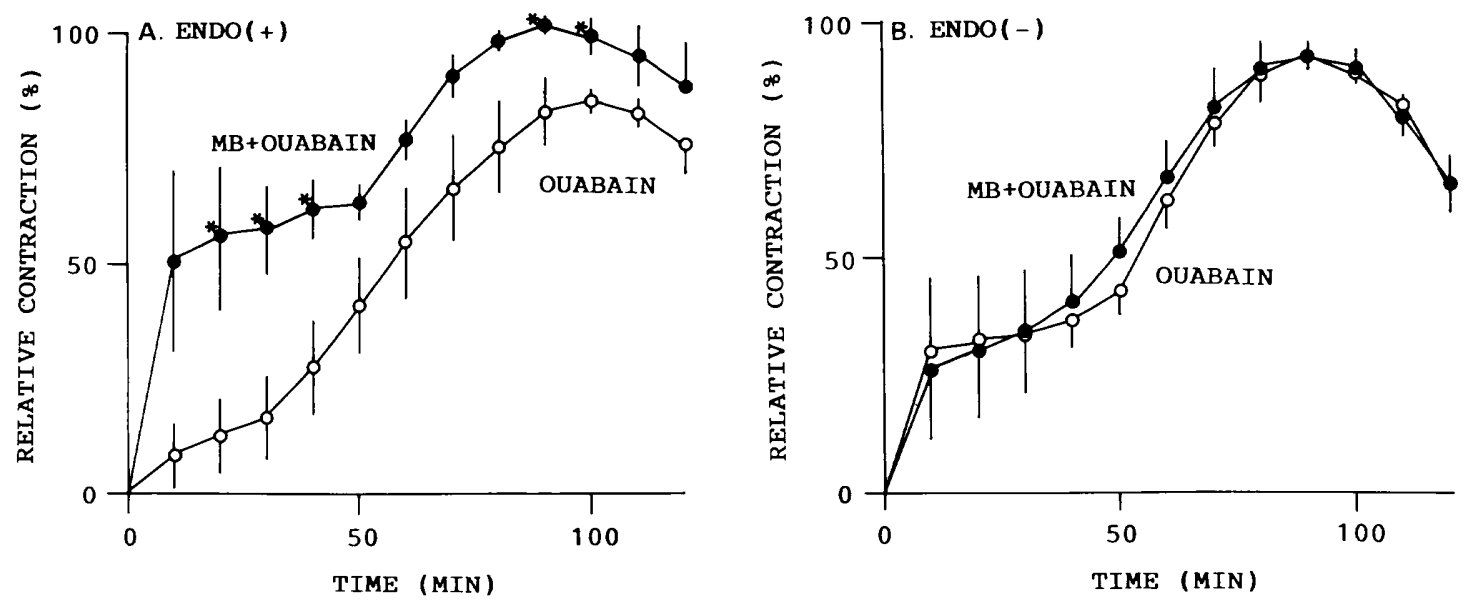

Fig. 2. Effect of $5 \mu \mathrm{M}$ methylene blue $(\mathrm{MB})$ on the ouabain-induced contractions in rat aortic strips with $(A)$ or without $(B)$ endothelium. Methylene blue was added $15 \mathrm{~min}$ before the application of ouabain or $\mathrm{K}^{+}$-free solution. Each curve represents the mean of 4 experiments. *: Significantly different from the value in the absence of methylene blue at the level of $P<0.05$. ENDO $(+)$ and ENDO(-): with and without endothelium, respectively.

and an inhibitor of cyclooxygenase, $20 \mu \mathrm{M}$ indomethacin, on ouabain-induced contractions are shown in Fig. $1 \mathrm{~A}$ and Table 1. Verapamil increased the latency period and decreased the peak tension of the ouabaininduced contraction. In contrast to this, indomethacin decreased the peak tension without changing the latency period. Verapamil and indomethacin showed an additive inhibitory effect on the peak tension of the ouabain-induced contraction, although a small contraction was still induced by ouabain in the presence of these two inhibitors. The same concentration of verapamil completely inhibited the high $\mathrm{K}^{+}$-induced contraction, whereas $20 \mu \mathrm{M}$ indomethacin had no effect on it (data not shown).

As shown in Fig. 1B and Table 1, verapamil 
Table 2. Effects of endothelium and methylene blue $(5 \mu \mathrm{M})$ on the contractions induced by ouabain $(1 \mathrm{mM})$ and $\mathrm{K}^{+-}$-free solution in rat aorta

\begin{tabular}{|c|c|c|c|c|}
\hline & $\begin{array}{l}\text { Time to } 10 \% \\
\text { peak tension } \\
(\min )\end{array}$ & $\begin{array}{c}\text { Time to } \\
\text { peak tension } \\
(\mathrm{min})\end{array}$ & $\begin{array}{l}\text { Peak tension } \\
\text { level } \\
(\%)\end{array}$ & $N$ \\
\hline \multicolumn{5}{|l|}{ Ouabain } \\
\hline Endothelium (-) & $5.3 \pm 1.6$ & $91.6 \pm 6.8$ & $95.1 \pm 2.3$ & 4 \\
\hline + Methylene blue & $5.0 \pm 2.2$ & $93.3 \pm 7.7$ & $93.5 \pm 3.3$ & 4 \\
\hline Endothelium (+) & $10.8 \pm 3.5^{* *}$ & $98.8 \pm 8.0$ & $84.5 \pm 2.8$ & 4 \\
\hline + Methylene blue & $5.1 \pm 2.2$ & $92.2 \pm 4.6$ & $101.2 \pm 3.8$ & 4 \\
\hline \multicolumn{5}{|l|}{$\mathrm{K}^{+}-$free solution } \\
\hline Endothelium (-) & $24.5 \pm 3.1$ & $88.3 \pm 7.0$ & $82.5 \pm 6.5$ & 4 \\
\hline + Methylene blue & $25.5 \pm 3.3$ & $95.2 \pm 6.3$ & $70.3 \pm 4.4$ & 4 \\
\hline Endothelium (+) & $36.6 \pm 4.2^{* *}$ & $89.5 \pm 5.5$ & $78.9 \pm 7.5$ & 4 \\
\hline + Methylene blue & $19.1 \pm 3.2$ & $101.3 \pm 3.9$ & $80.8 \pm 4.5$ & 4 \\
\hline
\end{tabular}

Peak tension is shown by relative value taking the high $\mathrm{K}^{+}$-induced contraction as $100 \%$. N: Number of experiments. **: Significantly different from the value in endothelium (-) at the level of $P<0.01$.
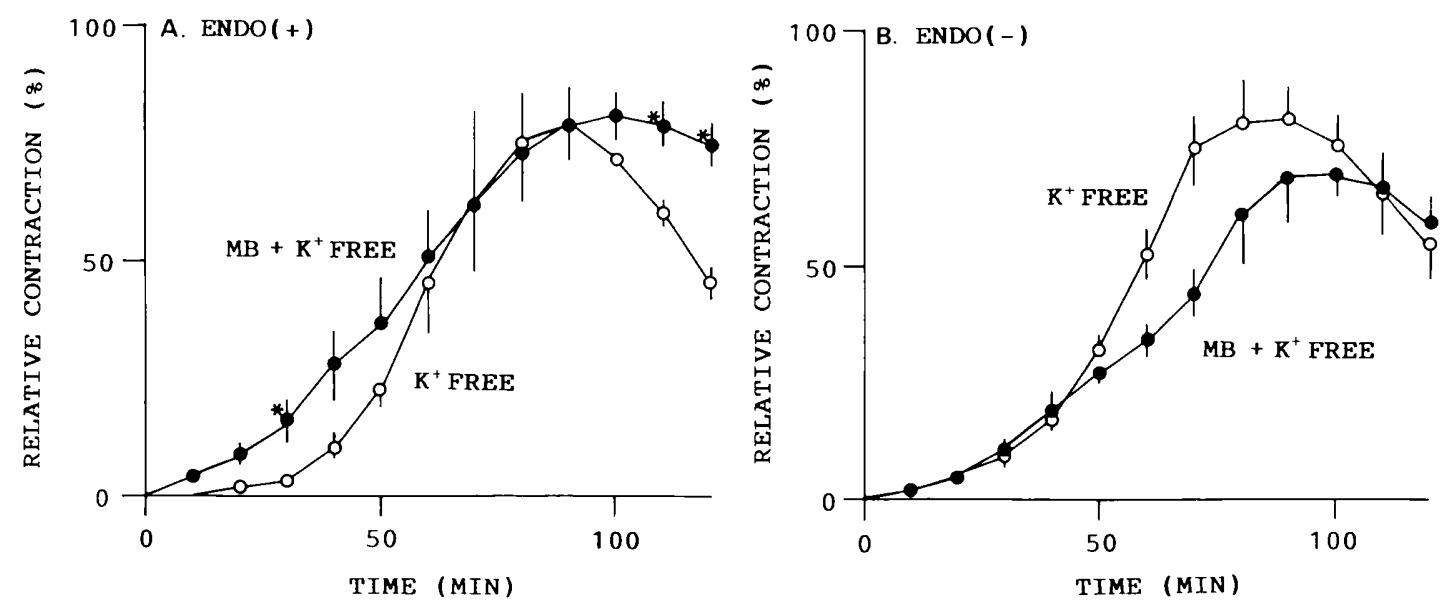

Fig. 3. Effect of $5 \mu \mathrm{M}$ methylene blue (MB) on the contraction induced by $\mathrm{K}^{+}$-free solution in rat aortic strips with $(A)$ or without $(B)$ endothelium. ": Significantly different from the value in the absence of methylene blue with $\mathrm{P}<0.05$. $\mathrm{ENDO}(+)$ and $\mathrm{ENDO}(-)$ : with and without endothelium, respectively.

increased the latency period and decreased the peak tension of the contraction induced by $\mathrm{K}^{+}$-free solution. In contrast to this, indomethacin decreased the peak contractile tension without changing the latency period. In the presence of both verapamil and indomethacin, the peak tension of this contraction was more strongly, but not completely. inhibited. These results are essentially the same as those in the ouabain-induced contraction.
As shown in Fig. 2 and Table 2, ouabain induced a contraction also in the aorta with endothelium. Comparing the contractions in the presence (Fig. 2A) and absence (Fig. 2B) of endothelium, the latency period of the contraction was longer in the presence of endothelium although the peak tension levels were almost the same (Table 2). In the presence of $5 \mu \mathrm{M}$ methylene blue, the latency period in the aorta with endothelium became shorter. However, methylene blue was 
ineffective in the aorta without endothelium.

Contractions induced by $\mathrm{K}^{+}$-free solution in the presence and absence of endothelium are shown in Fig. 3. Comparing these contractions, the latency period was longer in the presence of endothelium than in the absence, whereas the peak tension level did not change (Table 2). Methylene blue shortened the latency period only in the presence of endothelium, as is the case with ouabain-induced contraction.

\section{Discussion}

In rat aorta, ouabain and $\mathrm{K}^{+}$-free solution induced, after a latency period, a slow increase of muscle tension culminating $80-100$ min after the addition of ouabain or $\mathrm{K}^{+}$-free solution. The maximum contractile tension induced by ouabain and $\mathrm{K}^{+}$-free solution was more than $80 \%$ of the contraction induced by high $\mathrm{K}^{+}$solution. In the presence of indomethacin, an inhibitor of cyclooxygenase, the maximum level of the contraction induced by ouabain or $\mathrm{K}^{+}$-free solution was decreased without changing the latency period. The same concentration of indomethacin did not inhibit the high $\mathrm{K}^{+}$-induced contraction. These results suggest that ouabain and $\mathrm{K}^{+}$free solution release prostaglandins to induce contraction in isolated rat aorta. $\mathrm{K}^{+}$-depletion has been shown to stimulate prostacyclin synthesis in rat aortic strips (18). Ouabain and $\mathrm{K}^{+}$-depletion also stimulate the release of prostaglandin $\mathrm{E}$ in guinea pig taenia caeci (19). We did not identify the vasoconstrictor prostaglandins released by ouabain or $\mathrm{K}^{+}$free solution in this experiment. However, prostaglandin $E_{2}$, which has been shown to contract various vascular smooth muscle including rat aorta (20), may be one of the candidates.

It is possible that either inhibition of $\mathrm{Na}^{+}, \mathrm{K}^{+}$-ATPase or accumulation of $\mathrm{Na}^{+}$in the cell is responsible for the ouabain- and $\mathrm{K}^{+}$depletion-induced release of prostaglandin(s). Nagase and Karaki (21) have reported in rat aorta that the marine toxin palytoxin releases prostaglandins. This toxin does not inhibit $\mathrm{Na}^{+}, \mathrm{K}^{+}$-ATPase activity but directly increases membrane permeability to $\mathrm{Na}^{+}$(22). Further, it has been shown that a decrease of extracellular $\mathrm{Na}^{+}$inhibits and a
$\mathrm{Na}^{+}$ionophore, monensin, potentiates the contractions induced by ouabain and $\mathrm{K}^{+}$ depletion in rat aorta (23). These results indicate that the decrease in the transmembrane gradient of $\mathrm{Na}^{+}$may be responsible for the release of prostaglandins.

Verapamil prolonged the latency period and decreased the peak tension of the contraction induced by ouabain and $\mathrm{K}^{+}$-free solution. In contrast to this, indomethacin decreased the peak tension without changing the latency period. A combination of verapamil and indomethacin further depressed the peak tension. These results indicate that these contractions are composed of different components. Inhibition of $\mathrm{Na}^{+}, \mathrm{K}^{+}$-ATPase activity results in the membrane depolarization (24) because this enzyme plays a role as an electrogenic $\mathrm{Na}^{+}$pump (2). Since verapamil is a potent inhibitor of the voltage-dependent $\mathrm{Ca}^{2+}$ channel, the verapamil-sensitive portion of the contraction (with short latency period) induced by ouabain and $\mathrm{K}^{+}$-free solution may be attributable to membrane depolarization. In contrast to this, the indomethacin-sensitive contraction with longer latency period may be due to the release of prostaglandins. Further, since the contraction induced by $\mathrm{Na}^{+}-\mathrm{Ca}^{2+}$ exchange is not inhibited by verapamil (13), the small contraction remaining in the presence of both verapamil and indomethacin may be attributable to $\mathrm{Ca}^{2+}$ entry mediated by this mechanism.

These results indicate the striking qualitative similarity between the contractions induced by ouabain and $\mathrm{K}^{+}$-free solution. If we assume that the mechanism of action of ouabain and $\mathrm{K}^{+}$-free solution is to inhibit the $\mathrm{Na}^{+}, \mathrm{K}^{+}$-ATPase, the effects of ouabain and $\mathrm{K}^{+}$-free solution should be identical. However, quantitative comparison of the results shows some difference: the latency period was shorter in the ouabain-induced contraction than those in the contraction induced by $\mathrm{K}^{+}$free solution. The different effects of ouabain and $\mathrm{K}^{+}$-free solution may be due to different time courses of action; ouabain might inhibit the enzyme faster than $\mathrm{K}^{+}$-free solution does. Further, ouabain might have an additional effect that $\mathrm{K}^{+}$-depletion does not have; since ouabain, but not $\mathrm{K}^{+}$-free solution, potentiates the norepinephrine-induced contraction in 
rabbit aorta (10), ouabain may potentiate its own contractile effect and thus induces a contraction with a shorter latency period.

In the aorta with endothelium, ouabain and $\mathrm{K}^{+}$-free solution induced contractions which had similar maximum tension as that in the absence of endothelium. However, the latency period was slightly but significantly longer in the aorta without endothelium. Furchgott and Zawadzki (17) have shown that a relaxing substance(s) is released from the vascular endothelium which is termed as endothelium-derived relaxing factor (EDRF). Methylene blue, an inhibitor of the relaxation due to EDRF (25), shortened the latency period in the presence of endothelium. suggesting that EDRF inhibits the initial portion of these contractions. Rubanyi and Vanhoutte (26) reported that ouabain inhibits the release of EDRF in coronary artery. From these results, it is assumed that the ouabaininduced contraction is inhibited by spontaneously released EDRF and then ouabain inhibits the release of EDRF. Effect of endothelium on the contraction induced by $\mathrm{K}^{+}$-free solution may be attributable to a similar mechanism.

In conclusion, the present results suggest that the contractions of rat aorta induced by ouabain and $\mathrm{K}^{+}$-free solution are not only due to membrane depolarization and $\mathrm{Na}^{+}-\mathrm{Ca}^{2+}$ exchange but also due to the release of prostaglandins. Endothelium-derived relaxing factor seems to inhibit a part of these contractions.

Acknowledgments: We are grateful to Dr. Hiromi Nagase of our Department for her helpful suggestion. This work was supported by a Grant-in-Aid for Scientific Research from the Ministry of Education. Science and Culture, Japan.

\section{References}

1 Casteels, R., Droogmans, G. and Hendrickx, H.: Membrane potential of smooth muscle cells in K-free solution. J. Physiol. (Lond.) 217, 281295 (1971)

2 Hendrickx, H. and Casteels, R.: Electrogenic sodium pump in arterial smooth muscle cells. Pflugers Arch. 346, 299-306 (1974)

3 Casteels, R.: Tha action of ouabain on the smooth muscle cells of the guinea-pig's taenia coli. J. Physiol. (Lond.) 184, 131-142 (1966)

4 Axelsson, J. and Holmberg, B.: The effect of $\mathrm{K}^{+}$- free solution on tension development in the smooth muscle taenia coli frcm the guinea pig. Acta Physiol. Scand. 82, 322-332 (1971)

5 Ozaki, $H$. and Urakawa, N.: Effect of K-free solution on tension and $\mathrm{Na}$ content in vascular smooth muscles isolated from guinea-pig, rat and rabbit. Pflugers Arch. 389, 189-193 (1981)

6 Tomita, T. and Yamamoto, T.: Effect of removing the external potassium on the smooth muscle of guinea-pig taenia coli. J. Physiol. (Lond.) 212, 851-868 (1971)

7 Ozaki, H., Ishida, Y. and Urakawa, N.: Properties of contractions induced by ouabain and $\mathrm{K}^{+}$-free solution in guinea pig taenia coli. Eur. J. Pharmacol. 50, 9-15 (1978)

8 Ozawa, H. and Katsuragi, T.: Ouabain-induced potentiation on the contractions of the guineapig vas deferens. Eur. J. Pharmacol. 25, 147-154 (1974)

9 Karaki, H. and Urakawa, N.: Possible role of endogenous catecholamines in the contractions induced in rabbit aorta by ouabain, sodium depletion and potassium depletion. Eur. J. Pharmacol. 43, 65-72 (1977)

10 Karaki, H., Ozaki, H. and Urakawa, N.: Effect of ouabain and potassium-free solution on the contraction of isolated blood vessels. Eur. J. Pharmacol. 48, 439-443 (1978)

11 Bonaccorsi, A., Hermsmeyer, K., Smith, B. and Bohr, D.F.: Norepinephrine release in isolated arteries induced by K-free solution. Am. J. Physiol. 232, H140-145 (1977)

12 Ozaki, H. and Urakawa, N.: Possible role of $\mathrm{Na}$ $\mathrm{Ca}$ exchange mechanisms in the contractions induced in guinea-pig aorta by potassium free solution and ouabain. Naunyn Schmiedebergs Arch. Pharmacol. 304, 203-209 (1978)

13 Ozaki, H. and Urakawa, N.: Na-Ca exchange and tension development in guinea-pig aorta. Naunyn Schmiedebergs Arch. Pharmacol. 309, 171-178 (1979)

14 Vanhoutte, P.M., Verbeuren, T.J. and Webb, R.C.: Local modulation of adrenergic neuroeffector interaction in the blood vessel wall. Physiol. Rev. 61, 151-247 (1981)

15 Murakami, K., Karaki, H. and Urakawa, N.: Role of endothelium in the contractions induced by norepinephrine and clonidine in rat aorta. Japan. J. Pharmacol. 39, 357-364 (1985)

16 Nagase, H., Karaki, H. and Urakawa, N.: Palytoxin-induced endothelium-dependent relaxaticn in the isolated rat aorta. Naunyn Schmiedebergs Arch. Pharmacol. 335, 575-579 (1987)

17 Furchgott, R.F. and Zawadzki, J.V.: The obligatory role of endothelial celis in the relaxation of 
arterial smooth muscle by acetylcholine. Nature 288, 373-376 (1980)

18 Düsing, R., Scherhag, R., Tippelmann, R., Buddle, U., Glanzer, K. and Kramer, H.J.: Arachidonic acid metabolism in isolated rat aorta: Dependence of prostacyclin biosynthesis on extracellular potassium concentration. J. Biol. Chem. 257, 1993-1996 (1982)

19 Coburn, R.F. and Soltoff, S.: $\mathrm{Na}^{+}-\mathrm{K}^{+}-\mathrm{ATP}$ ase inhibition stimulates $P G E$ release in guinea pig taenia coli. Am. J. Physiol. 232, C191-C195 (1977)

20 Needleman, P. and Isakson, P.C.: Intrinsic prostaglandin biosynthesis in blood vessels. In Handbook of Physiology. Section 2. The Cardiovascular System, Vol. 2, Vascular Smooth Muscle, Edited by Bohr, D. F., Somlyo, A. P. and Sparks, H.V., Jr. p. 613-633, Williams and Wilkins Co., Baltimore (1980)

21 Nagase, $H$. and Karaki, H.: Palytoxin-induced contraction and release of prostaglandins and norepinephrine in the aorta. J. Pharmacol. Exp. Ther. 242, 1120-1125 (1987)

22 Ozaki, H., Nagase, H. and Urakawa, N.: Inter- action of palytoxin and cardiac glycosides on erythrocyte membrane and $\left(\mathrm{Na}^{+}+\mathrm{K}^{+}\right)$ATPase. Eur. J. Biochem. 152, 475-480 (1985)

23 Moreland, R.S., Major, T.C. and Webb, R.C.: Contractile responses to ouabain and $\mathrm{K}^{+}$-free solution in aorta from hypertensive rats. Am. J. Physiol. 250, H612-H619 (1986)

24 Belardinelli, L., David, H., Sperelakis, N., Rubio, R. and Berne, R.M.: Cardiac glycoside stimulation of inward $\mathrm{Ca}^{++}$current in vascular smooth muscle of canine coronary artery. J. Pharmacol. Exp. Ther. 209, 62-66 (1979)

25 Gruetter, C.A., Gruetter, D.Y., Lyon, J.E., Kadowitz, P.J. and Ignarro, L.J.: Relationstip between cyclic guanosine $3^{\prime}, 5^{\prime}$-monophosphate formation and relation of coronary arterial smooth muscle by glyceryl nitrate, nitroprusside, nitrite, and nitric oxide: effects of methylene blue and methohemoglobin. J. Pharmacol. Exp. Ther. 219, 181-186 (1981)

26 Rubanyi, G.M. and Vanhoutte, P.M.: Ouabain inhibits endothelium-dependent relaxation to arachidonic acid in canine coronary arteries. J. Pharmacol. Exp. Ther. 235, 81-86 (1985) 